\title{
Measuring the Quality and Requirements of the Labor Market in the Curriculum of Saudi Business Schools( An applied study on the College of Business Administration, Prince Sattam bin Abdulaziz University)
}

\author{
Nabil Mohemmed Al-Hazmi, Associate Professor of Marketing, Department of Marketing, College of \\ Business Administration Prince Sattam bin Abdulaziz University-Kingdom of Saudi Arabia, \\ n.alhazmi@psau.edu.sa
}

\begin{abstract}
This study aims at measuring the compatibility of the curricula of the College of Business Administration with the requirements of quality education and in line with the needs of the labor market and the requirements of development in the Kingdom of Saudi Arabia. The study used the descriptive and analytical approach to reach the achievement of its objectives and test its hypothesis by distributing a questionnaire form to students of the various departments in the college. The study reached a set of results, the most important of which is the weakness of linking learning outcomes with the objectives of the curricula and not focusing the curricula units on developing students' skills. The study presented a set of recommendations, the most important of which is focusing on learning outcomes and a comprehensive review of the current curricula. In addition to coordination with the labor market and the local community when preparing the college's curricula, as well as linking the curricula with the country's comprehensive development plans and launching new specializations.
\end{abstract}

Keywords: Education, Quality, Labor Market, Curriculum, Business Schools, Total Quality Management. Received: 03.12.2020 Accepted: 12.01.2021 $\quad$ Published: 02.02.2021

\section{INTRODUCTION}

The quality of higher education is identified as the characteristics and features, which ensure graduating educated and qualified individuals in line with the requirements of the labor market and society and all other institutions inside or outside the kingdom, which would increase the supremacy of the kingdom. To achieve this quality, it requires directing all human resources, various systems, policies, and infrastructure to create appropriate conditions, which will bring out the conscious and educated individual. In this article, we will investigate the quality standards, which must be met in higher education.

To achieve quality in higher education, there are a set of standards that must be met, including:

- The scientific curricula should cover all the necessary basic topics to learn a specialization, with the necessity of adapting these topics to the realities of life lived and commensurate with the needs of the market. Besides, these curricula should develop the students' analytical capacity and helps in thinking, research, teamwork, and various practical and applied activities, which develop the student's personality, with the need to prepare the student for the globalization era in which we live by teaching him at least one foreign language.

- The reliance of the scientific method on scientific references that are distinguished by their high level of knowledge, reliability, and originality, and attention must be paid to the approach of explaining and presenting this reference and making it at affordable prices in line with the conditions of most students.

- Selecting the faculty members carefully according to certain characteristics; including the scientific and moral level, the national sense, acceptance of feedback and constructive criticism, the creating students' innovation and development skills, motivation and support, commitment to the proposed scientific curricula. In addition to the development of the student's spirit of researching and thinking, away from the method of passive learning, conservation, and non-activating the mind.

- Considering the method of evaluation through which students are evaluated with the ability of students' critical analyzing and thinking, away from memorization.

- The administrative system should have sufficient qualifications to be capable to proficiently and effectively manage the educational system in a way that serves the students' interest, society, and the labor market, and to move away from the method of intimidation and threatening, granting workers' confidence, motivation and encouragement to perform the tasks entrusted to them in the best way 
without interfering in others' specialization, and the need to set general objectives to achieve the success of the educational institution and to develop strategic plans to achieve the objectives.

- The availability of clear and specific goals for education in all educational institutions, and the development of the necessary plans to achieve these goals with the need to adhere to these plans.

- Providing material facilities in education so that it is accessible by all, and providing material resources which would take care of the aesthetics of educational institutions in a way that gives beauty and psychological comfort to students, the teaching and administrative staff, it motivates each individual to perform his duty properly. The accurate approach that higher education institutions must follow is subjected to the requirements of the labor market by controlling the quality of specializations and curricula, preparing students in every major, and organizing and managing the university in light of this principle. This requires profound procedures and changes in the structure of universities. It also requires comprehensive studies on the present and future labor market including being acquainted with real labor markets, and how to provide the necessary competency, preparing studies, plans, and questionnaires that universities and university professors undertake and is carried out through them, and according to internationally approved scientific standards, clarifying the needs of society and the labor market, the priorities of those needs and the requirements for their accomplishment. The College of Business Administration at Prince Sattam bin Abdulaziz University is one of the scientific colleges at the university, which provides educational services through its various departments (Marketing - Management Administrative Information Systems - Accounting - Financial). The college seeks to constantly update its programs and plans in line with the requirements of the labor market and the requirements of development in the Kingdom of Saudi Arabia. Besides, the college seeks to have compatibility between its objectives and the learning outcomes that it aims to achieve in light of its constant endeavor to obtain internal and international academic accreditation.

\section{Study Problem}

There is an increasing interest by industrial and service business organizations in Total Quality Management TQM and labor market requirements. Quality has become one of the strategic levels of competition and excellence over competitors. The problem appears clearer the more the principles of TQM are applied in competing organizations and linked to the requirements of the labor market, and excellence over competitors. The problem appears clearer the more the principles of TQM are applied in competing institutions and linked to the requirements of the labor market. The problem becomes clearer when more principles of TQM are applied in competing institutions and linked to the requirements of the labor market. The College of Business Administration at Prince Sattam bin Abdulaziz University seeks to obtain internal and international academic accreditation through applying a set of quality and accreditation standards where the problem of compatibility of the college curricula with quality requirements appears

\section{Study Importance}

The importance of this study is clearly stated by:

1- The study is the first of its kind to be conducted in this field at the college.

2- Supporting the spread of the TQM culture in the college and university.

3- Striving to improve the educational outcomes in the college by adopting the principle of continuous improvement and relying on the principles of TQM.

\section{Study objectives}

The study aims at measuring the compatibility of the curricula of the College of Business Administration with the requirements of the quality of education and in line with the needs of the labor market and the requirements of development in the Kingdom of Saudi Arabia.

\section{Study hypothesis}

The study seeks to test the following hypothesis:

There is no statistically significant relationship at the level (0.05) between the curricula of the College of Business Administration and the requirements of the labor market.

\section{Study limitations}

The study limits are:

Spatial limitation: The study was conducted at the College of Business Administration at Prince Sattam Bin Abdulaziz University.

Time limitation: Conducted from March 2020 until December 2020. 
Objective limitation: The study dealt with the issue of measuring the requirements for quality education in the College of Business Administration.

\section{Study population \& sample}

The study population is represented by the College of Business Administration students at Prince Sattam bin Abdulaziz University, as 200 students were randomly selected as a sample for the study according to the following table:

Table 1 Distribution of the study sample among the various departments in the college.

\begin{tabular}{|r|r|r|r|}
\hline $\mathbf{N}$. & Departments & Sample size & The ratio of $\mathbf{1 0 0 \%}$ \\
\hline 1 & Accounting & 45 & 22.5 \\
\hline 2 & Finance & 35 & 17.5 \\
\hline 3 & Management Information Systems & 30 & 15 \\
\hline 4 & Human resource management & 45 & 22.5 \\
\hline 5 & Law & 45 & 22.5 \\
\hline \multicolumn{2}{r|}{ Total } & 200 & 100 \\
\hline
\end{tabular}

\section{Literature Review}

Many studies are dealing with the quality of education in colleges of business administration in the Kingdom of Saudi Arabia, but some studies dealt with the issue of education quality in general, including the study (Al-Hazmi, 2020). The study dealt with the importance of internal marketing in achieving comprehensive TQM at Prince Sattam bin Abdulaziz University, and it recommended the need to pay more attention to the relationship with faculty members at the university and the need to qualify them with methods and techniques Modern. The study (Nazir, 2017) recommended the necessity of referring to the requirements of the labor market and the goals of comprehensive development when desiring to prepare or develop curricula for private colleges and universities in Iraq. The study (Ahmed, 2019) also aimed at identifying the quality of education in private universities and its impact on the values of sustainable development. It is recommended that the administration in private university education should adopt the philosophy of education quality and its applications to meet the severe challenges in the business environment characterized by rapid development. The study (Alheliwo, 2020) recommended that attention should be paid to improve the quality of students' life at the university and work to enhance these concepts through the curricula which must be in line with the variables of the social and economic environment to enhance learning outcomes. The study (Hassan, 2019) aimed at measuring the quality of education among faculty members in universities. Besides, it recommended the necessity of training faculty members in modern methods and methods of education and linking the objectives of the curricula with the learning outcomes and diversifying the activities provided to students. The study (KESO, 2019) aimed at finding out how to achieve the development of accounting education in the accounting departments of business schools, and it recommended the establishment of committees within the department to monitor the quality of the educational process with the participation of faculty members in a changing environment. The study (Sabri, 2019) aimed at measuring the quality of higher education in Jordanian universities and recommended the necessity of adopting clear and easy-to-apply standards to achieve the quality of higher education. The study (Mehri, 2017) also aimed to establish and set standards for quality in higher education because of its importance in ensuring the achievement of comprehensive quality in educational outcomes. The study (Al-Sayed, 2019) recommended working on preparing comprehensive strategies to develop the quality of university education to guarantee quality in the learning process and quality in higher education outcomes to keep pace with the changes which occur at the national and international levels.

Through our review of previous studies, we find that they were conducted in other universities and colleges and different periods and did not address the issue of measuring the quality of education requirements in colleges of business administration. Hence, this study is distinguished from previous studies in that it was conducted in the College of Business Administration at Prince Sattam bin Abdulaziz University and dealt with the issue of measuring the quality and requirements of the labor market in the curriculum of the College of Business Administration.

\section{Study methodology}

To achieve the objectives of this study, the descriptive and analytical method was used to present the different aspects of quality and its standards in the curricula of the College of Business Administration, Prince Sattam bin Abdulaziz University.

To carry out the field study to cover the practical side of this study, a questionnaire form was prepared that measures and reveals the level of quality standards and labor market requirements available in the 
curriculum of the College of Business Administration. The five-point Likert scale with a value of 1 to 5 was relied on.

\begin{tabular}{|l|l|l|l|l|l|}
\hline Phrase & Strongly disagree & disagree & Neutral & agree & Strongly agree \\
\hline Value & 1 & 2 & 3 & 4 & 5 \\
\hline
\end{tabular}

\section{Study tool}

The questionnaire was designed based on (Nathier.2017) and was distributed to the sample members of the College of Business Administration students to measure the quality of education in the college's curricula. The questionnaire form included seven basic axes to ascertain the validity of the study hypothesis, and each axis includes a set of questions as follows:

The first axis: includes a set of questions about the educational objectives of the curriculum.

The second axis: includes a set of questions about the content of the curriculum.

The third axis: includes a set of questions about teaching and learning methods.

The fourth axis: includes a set of questions about educational activities.

The fifth axis: includes a set of evaluation questions.

The sixth axis: includes a set of questions about the relationship with the labor market.

The seventh axis: includes a set of questions about training.

\section{Tool validity}

To identify the suitability of the questionnaire form for the objectives of the study and to test its hypothesis and its ability to measure its variables, the questionnaire was presented to a group of specialists in administration and management of education and quality at Prince Sattam bin Abdulaziz University, King Khalid University, King Saud University, Taiz University, and Kafr El-Sheikh University to guarantee the clarity and accuracy of the statements in measuring what they were designed for. The comments of the arbitrators were taken into consideration, and to test the internal consistency of the questionnaire, the coherence coefficient (Alpha Cronbach) was used, reached the scale as a whole (0.926).

Table 2 Stability coefficient, Alpha Cronbach of the study.

\begin{tabular}{|r|r|r|}
\hline No. & Study axes & $\begin{array}{r}\text { Cronbach's } \\
\text { Coefficient Alpha }\end{array}$ \\
\hline $\mathbf{1}$ & The Educational Objectives Of The Curriculum & 0.919 \\
\hline $\mathbf{2}$ & Curriculum Content & 0.923 \\
\hline $\mathbf{3}$ & Methods Of Teaching And Learning & 0.924 \\
\hline $\mathbf{4}$ & Educational Activities & 0.912 \\
\hline $\mathbf{5}$ & Evaluation Questions & 0.894 \\
\hline $\mathbf{6}$ & Relationship With The Labor Market & 0.904 \\
\hline $\mathbf{7}$ & Training & 0.931 \\
\hline & Total & 0.926 \\
\hline
\end{tabular}

\section{Data Analyses}

First: Analyzing the study sample responses to quality standards and labor market requirements in the curricula of the College of Business Administration.

The study sample answers were distributed on the various axes as follows:

\section{The educational objectives of the Curriculum}

Table 3 The educational objectives of the Curriculum.

\begin{tabular}{|l|l|l|l|l|l|}
\hline No. & The educational objectives of the curricula & Mean & $\begin{array}{r}\text { St } \\
\text { dev. }\end{array}$ & $\begin{array}{l}\text { Relative } \\
\text { weighting }\end{array}$ & Degree \\
\hline 1 & $\begin{array}{l}\text { The educational goals are appropriate for the future } \\
\text { preparation of students }\end{array}$ & $\mathbf{2 . 6 2 6}$ & $\mathbf{1 . 6 0 4}$ & $\mathbf{0 . 3 0 2}$ & Medium \\
\hline 2 & $\begin{array}{l}\text { The educational goals are in line with contemporary } \\
\text { trends in the knowledge society }\end{array}$ & $\mathbf{1 . 5 2 1}$ & $\mathbf{1 . 0 0 0}$ & $\mathbf{0 . 5 9 2}$ & Low \\
\hline 3 & $\begin{array}{l}\text { The curricula covers the students' skills and emotional } \\
\text { aspects }\end{array}$ & $\mathbf{2 . 4 6 3}$ & $\mathbf{1 . 3 0 2}$ & $\mathbf{0 . 5 6 4}$ & Medium \\
\hline 4 & The curriculum covers the students' basic knowledge & $\mathbf{3 . 4 1 0}$ & $\mathbf{1 . 1 0 2}$ & $\mathbf{0 . 6 3 0}$ & High \\
\hline
\end{tabular}




\begin{tabular}{|l|l|l|l|l|l|}
\hline 5 & $\begin{array}{l}\text { There is a connection between the curricula objectives } \\
\text { and the requirements of society and the labor market }\end{array}$ & $\mathbf{1 1 0}$ & $\mathbf{0 . 6 3 0}$ & High \\
\hline 6 & $\begin{array}{l}\text { Taking into consideration the balance between } \\
\text { theoretical, applied, and practical aspects }\end{array}$ & 1.421 & $\mathbf{0 . 9 1 0}$ & $\mathbf{0 . 5 9 2}$ & Low \\
\hline The overall arithmetic mean & 2.865 & $\mathbf{0 . 8 9 1}$ & $\mathbf{0 . 5 9 2}$ & Medium \\
\hline
\end{tabular}

\section{Curriculum content}

Table 4 Curriculum content

\begin{tabular}{|c|c|c|c|c|c|}
\hline No. & Curriculum content & Mean & St dev. & $\begin{array}{l}\text { Relative } \\
\text { weighting }\end{array}$ & Degree \\
\hline 1 & It assists to learn the skill and emotional side & 1.420 & 0.983 & 0.571 & Low \\
\hline 2 & Content is aligned with cognitive goals & 3.521 & 1.314 & 0.645 & High \\
\hline 3 & $\begin{array}{l}\text { It keeps pace with modern knowledge and scientific } \\
\text { developments }\end{array}$ & 1.412 & 0.961 & 0.586 & Low \\
\hline 4 & Balances the theoretical, applied, and practical aspects & 2.431 & 1.581 & .491 & Medium \\
\hline 5 & $\begin{array}{l}\text { Take into consideration the relay topics of the } \\
\text { curriculum during the different grades }\end{array}$ & 2.748 & 1.643 & 0.552 & Medium \\
\hline 6 & The course content is presented. & 2.832 & 1.656 & 0.564 & Medium \\
\hline 7 & Helps to develop innovative problem-solving skills & 2.329 & 1.496 & 0.452 & Medium \\
\hline 8 & Helps to gain thinking skills. & 2.636 & 1.521 & 0.523 & Medium \\
\hline 9 & $\begin{array}{l}\text { Content design is student-centered and takes into } \\
\text { account individual differences between them. }\end{array}$ & 2.109 & 0.981 & 0.526 & Medium \\
\hline 10 & $\begin{array}{l}\text { Contributes to the development of cooperative learning } \\
\text { skills and working in a team }\end{array}$ & 2.237 & 0.993 & 0.539 & Medium \\
\hline \multicolumn{2}{|c|}{ The overall arithmetic mean } & 2.679 & 1.568 & 0.549 & Medium \\
\hline
\end{tabular}

Teaching and learning methods to achieve the curriculum objectives

Table 5 Teaching and learning methods to achieve the curriculum objectives.

\begin{tabular}{|l|l|r|r|r|r|}
\hline No. & $\begin{array}{l}\text { Teaching and learning methods to achieve the } \\
\text { curriculum objectives }\end{array}$ & Mean & $\begin{array}{r}\text { St } \\
\text { dev. }\end{array}$ & $\begin{array}{r}\text { Relative } \\
\text { weighting }\end{array}$ & Degree \\
\hline 1 & $\begin{array}{l}\text { Helps to develop the student's life-long learning } \\
\text { The learning environment helps to make effective use of } \\
\text { the time available for teaching }\end{array}$ & 3.756 & 0.621 & 0.645 & High \\
\hline 3 & $\begin{array}{l}\text { Teaching and learning methods contribute to providing } \\
\text { students with basic concepts, values, and positive } \\
\text { attitudes. }\end{array}$ & 3.002 & 0.610 & 0.631 & High \\
\hline 4 & $\begin{array}{l}\text { The learning environment provides various learning } \\
\text { resources suitable for all students }\end{array}$ & 3.596 & 0.702 & 0.710 & High \\
\hline 5 & $\begin{array}{l}\text { Contributes to the development of student's skills to } \\
\text { deal with and solve environmental problems. }\end{array}$ & 2.613 & 0.591 & 0.564 & Medium \\
\hline 6 & $\begin{array}{l}\text { Teaching and learning styles vary between group, } \\
\text { individual, and enrichment styles }\end{array}$ & 2.432 & 0.546 & 0.531 & Medium \\
\hline 7 & $\begin{array}{l}\text { Teaching and learning methods take into account } \\
\text { individual differences among students }\end{array}$ & 2.325 & 0.520 & 0.491 & Medium \\
\hline 8 & $\begin{array}{l}\text { It helps the student to use multiple sources of } \\
\text { knowledge and technology. }\end{array}$ & 3.124 & 0.682 & 0.671 & High \\
\hline 9 & $\begin{array}{l}\text { The learning environment helps to make effective use of } \\
\text { the time available for teaching }\end{array}$ & 3.324 & 0.694 & 0.683 & High \\
\hline 10 & $\begin{array}{l}\text { Teaching methods encourage the student to take } \\
\text { responsibility. }\end{array}$ & 2.581 & 0.599 & 0.534 & Medium \\
\hline 11 & $\begin{array}{l}\text { A variety of methods and sources are used to evaluate } \\
\text { students. }\end{array}$ & 3.184 & 0.694 & 0.689 & High \\
\hline The overall arithmetic mean & 3.109 & 0.685 & 0.669 & High \\
\hline
\end{tabular}


Educational activities in the content of the curriculum

Table 6 Educational activities in the curriculum content.

\begin{tabular}{|l|l|l|l|l|l|}
\hline No. & $\begin{array}{l}\text { Teaching and learning methods to achieve the } \\
\text { curriculum objectives }\end{array}$ & Mean & $\begin{array}{l}\text { St } \\
\text { dev. }\end{array}$ & $\begin{array}{l}\text { Relative } \\
\text { weighting }\end{array}$ & Degree \\
\hline 1 & $\begin{array}{l}\text { The activities take into account the objectives of the } \\
\text { curriculum in its dimensions: cognitive, skill, and } \\
\text { effective. }\end{array}$ & 2.923 & 0.592 & 0.568 & Medium \\
\hline 2 & $\begin{array}{l}\text { Contribute to developing the learner's skills in managing } \\
\text { the available time. }\end{array}$ & 3.258 & 0,698 & 0.701 & High \\
\hline 3 & $\begin{array}{l}\text { The educational activities are related to the curriculum } \\
\text { content }\end{array}$ & 3.441 & 1.096 & 0.752 & High \\
\hline 4 & $\begin{array}{l}\text { The activities vary according to the educational situation, } \\
\text { between class / non-class, and group/individual. }\end{array}$ & $\begin{array}{l}\text { Medium } \\
\text { related to the profession in which he specializes and } \\
\text { suggests solutions to them. }\end{array}$ & 0.612 & 0.592 & High \\
\hline 5 & $\begin{array}{l}\text { It drives the student to create and solve problems in an } \\
\text { innovative way. }\end{array}$ & 3.033 & 0.643 & 0.669 & High \\
\hline 7 & $\begin{array}{l}\text { Activities are concerned with the use of active learning } \\
\text { strategies: } \\
\text { educational games). }\end{array}$ & 2.102 & 0.510 & 0.510 & Medium \\
\hline 8 & $\begin{array}{l}\text { The student is directed towards studying and } \\
\text { investigating to obtain knowledge. }\end{array}$ & 3.142 & 0.664 & 0.664 & High \\
\hline The overall arithmetic mean & High \\
\hline
\end{tabular}

Evaluation (evaluation questions)

Table 7 Evaluation.

\begin{tabular}{|l|l|l|l|l|l|}
\hline No. & $\begin{array}{l}\text { Teaching and learning methods to achieve the } \\
\text { curriculum objectives }\end{array}$ & Mean & $\begin{array}{l}\text { St } \\
\text { dev. }\end{array}$ & $\begin{array}{l}\text { Relative } \\
\text { weighting }\end{array}$ & Degree \\
\hline 1 & $\begin{array}{l}\text { College administration pushes for curriculum } \\
\text { evaluation and development }\end{array}$ & 3.964 & 0.792 & 0.743 & High \\
\hline 2 & $\begin{array}{l}\text { The evaluation trains the student to analyze content and } \\
\text { give a high opinion }\end{array}$ & 2.521 & 0.801 & 0.521 & Medium \\
\hline 3 & There are standards for each element of the curriculum. & 2.132 & 0.761 & 0.491 & Medium \\
\hline 4 & $\begin{array}{l}\text { Evaluating field training and developing it according to } \\
\text { labor market protests }\end{array}$ & 3.410 & 0.912 & 0.631 & High \\
\hline 5 & Assessment questions measure aspects of learning & 3.100 & 0.998 & 0.629 & High \\
\hline 6 & Assessment questions guide creative thinking. & 2.756 & 0.924 & 0.537 & Medium \\
\hline The overall arithmetic mean & 3.396 & 0.905 & 0.644 & High \\
\hline
\end{tabular}

Relationship with the labor market

Table 8 The relationship with the labor market.

\begin{tabular}{|c|c|c|c|c|c|}
\hline No. & $\begin{array}{l}\text { Teaching and learning methods to achieve the } \\
\text { curriculum objectives }\end{array}$ & Mean & $\begin{array}{r}\text { St } \\
\text { dev. }\end{array}$ & $\begin{array}{l}\text { Relative } \\
\text { weighting }\end{array}$ & Degree \\
\hline 1 & $\begin{array}{l}\text { The college administration focuses on the continuous } \\
\text { updating of the curriculum to keep pace with any } \\
\text { changes in the needs and preferences of the labor } \\
\text { market. }\end{array}$ & 3.104 & 1.011 & 0.631 & High \\
\hline 2 & $\begin{array}{l}\text { The college has the necessary competence to qualify } \\
\text { graduates in the labor market. }\end{array}$ & 3.219 & 1.210 & 0.642 & High \\
\hline 3 & $\begin{array}{l}\text { There is cooperation between the college administration } \\
\text { and the labor market institutions. }\end{array}$ & 4.218 & 0.312 & 0.839 & High \\
\hline 4 & $\begin{array}{l}\text { Adaptation of the science majors in the college to the } \\
\text { needs of the labor market }\end{array}$ & 3.567 & 0.340 & 0.749 & High \\
\hline \multicolumn{2}{|c|}{ The overall arithmetic mean } & 3.454 & 0.315 & 0.758 & High \\
\hline
\end{tabular}


Table 9 Training.

\begin{tabular}{|l|l|l|l|l|l|}
\hline No. & $\begin{array}{l}\text { Teaching and learning methods to achieve the } \\
\text { curriculum objectives }\end{array}$ & Mean & $\begin{array}{r}\text { St } \\
\text { dev. }\end{array}$ & $\begin{array}{l}\text { Relative } \\
\text { weighting }\end{array}$ & Degree \\
\hline 1 & $\begin{array}{l}\text { Training is directed towards developing managerial } \\
\text { skills }\end{array}$ & 3.147 & 1.056 & 0.712 & High \\
\hline 2 & $\begin{array}{l}\text { Field training occupies a clear position when preparing } \\
\text { the curriculum }\end{array}$ & 3.302 & 1.259 & 0.743 & High \\
\hline 3 & $\begin{array}{l}\text { The period allocated for field training is suitable for } \\
\text { preparing students for the job market }\end{array}$ & 4.101 & 0.412 & 0.849 & High \\
\hline 4 & $\begin{array}{l}\text { Field training programs are adequate. } \\
\text { There is a follow-up for students by the college } \\
\text { administration in their places of training }\end{array}$ & 3.251 & 0.436 & 0.859 & High \\
\hline
\end{tabular}

By analyzing the data in tables 3 to 9 for the different axes, we find the following:

1- The arithmetic mean of most of the questions of the different axes ranged between the values (3) or slightly greater than it, and this means that the trend was positive according to the five Likert scales.

2- The standard deviation was within the range.

3- We find that the most positive paragraphs in the various axes were paragraph No. (4) The curriculum covers the basics of knowledge for students, paragraph No. (8) The content is consistent with the cognitive objectives, and Paragraph No. (18) Helps the learning environment to use the available time for teaching effectively. Paragraph No. (32) Graduation projects are directed towards problems related to the profession in which he specializes and proposes solutions to them. Paragraph No. (36) The college administration pushes for the evaluation and development of the curriculum, and paragraph No. (39) Evaluating field training and developing it according to labor market needs. In paragraph No. (44) There is a cooperation between the college administration and the labor market institutions, Paragraph No. 48. The period allotted for field training is appropriate to qualify students for the labor market, and Paragraph No. (50) There is a follow-up for students by the college administration at their training places. We find the least valuable paragraphs in the various axes. Paragraph No. (2) The educational objectives are in line with contemporary trends in the knowledge society, Paragraph No. (6) Takes into account the balance between the theoretical and practical aspects and the scientific aspects, and Paragraph No. (9) Keeps pace with modern knowledge and scientific developments. Paragraph No. (23) Teaching and learning methods are taken into consideration individual differences between students, paragraph (34) deals with activities using active learning strategies, and paragraph (38) there is standards for each element of the curriculum. This indicates the most important paragraphs, which contributed to enrich the relevant variables, this hypothesis supports the high ratios in the area of the scale, as well as the standard deviation, which was less than the correct one, and in turn, it indicates a case of low dispersion between the respondents' answers.

4- It is also clear that the answers which were greater than 4 were 4 by $8 \%$, answers greater than 3 were 26 by $52 \%$, and answers less than 3 were 20 by $40 \%$.

Table 10 The arithmetic means, the general standard deviation, and the degree of approval for all study variables.

\begin{tabular}{|c|c|c|c|c|c|c|}
\hline No. & \multicolumn{2}{|r|}{ Variables } & \multirow{2}{*}{$\begin{array}{r}\text { Degree } \\
2.865\end{array}$} & \multirow{2}{*}{$\begin{array}{r}\begin{array}{l}\text { Relative } \\
\text { weighting }\end{array} \\
0.891\end{array}$} & \multirow{2}{*}{$\begin{array}{r}\text { St dev. } \\
0.592\end{array}$} & \multirow{2}{*}{$\begin{array}{l}\text { Mean } \\
\text { Medium }\end{array}$} \\
\hline 1 & The & $\begin{array}{r}\text { Educational Objectives } \begin{array}{c}\text { Of The } \\
\text { Curriculum }\end{array} \\
\end{array}$ & & & & \\
\hline 2 & \multicolumn{2}{|r|}{ Curriculum Content } & 2.679 & 1.568 & 0.549 & Medium \\
\hline 3 & \multicolumn{2}{|r|}{ Methods Of Teaching And Learning } & 3.109 & 0.685 & 0.669 & High \\
\hline 4 & \multicolumn{2}{|r|}{ Educational Activities } & 3.325 & 1.023 & 0.725 & High \\
\hline 5 & \multicolumn{2}{|r|}{ Evaluation Questions } & 3.396 & 0.905 & 0.644 & High \\
\hline 6 & \multicolumn{2}{|r|}{ Relationship With The Labor Market } & 3.454 & 0.315 & 0.758 & High \\
\hline 7 & \multicolumn{2}{|r|}{ Training } & 3.914 & 0.409 & 0.831 & High \\
\hline \multicolumn{3}{|r|}{ Total } & 3.325 & 0.996 & 0.659 & High \\
\hline
\end{tabular}


From the above table, it becomes clear that the general arithmetic means of all axes reached (3.325) and a standard deviation (0.996), and we find that the best axis in the answers was the seventh axis (training) with arithmetic mean (3.914) and a standard deviation (0.409) and the lowest axis is the second axis (curriculum components) with a mean (0.592) and a standard deviation (1.568). Through the abovementioned, the results of the statistical analysis of the answers of the study sample support the hypothesis claiming that there are no statistically significant differences at the significance level $(\alpha \leq 0.05)$ in the averages of students 'estimates of quality standards and labor market requirements in the curriculum of the College of Business Administration at Prince Sattam Bin Abdulaziz.

Second: The factor analysis of quality standards and labor market requirements in the curriculum of the College of Business Administration.

We notice from Tables (11 and 12) that the results of the global analysis of quality standards and labor market requirements in the curriculum of the College of Business Administration, and the percentage of contribution of each worker in the curriculum, which was between (0.831) to (0.549) for the sequence of factors.

Table 11 Factor analysis of quality standards and labor market requirements in the curriculum of the College of Business Administration.

\begin{tabular}{|r|r|r|}
\hline No. & Variables & Contribution ratio \\
\hline 1 & The Educational Objectives Of The Curriculum & 0.642 \\
\hline 2 & Curriculum Content & 0.592 \\
\hline 3 & Methods Of Teaching And Learning & 0.669 \\
\hline 4 & Educational Activities & 0.725 \\
\hline 5 & Evaluation Questions & 0.644 \\
\hline 6 & Relationship With The Labor Market & 0.758 \\
\hline 7 & Training & 0.831 \\
\hline
\end{tabular}

Training in the sequence of factors of the factor analysis of quality standards and labor market requirements occupied the best level with a contribution rate of (0.831) and thus it represents the first factor in the answers of the study sample in the quality standards and requirements of the labor market in the college curriculum, followed by the relationship with the labor market with a contribution rate of (0.758). The factor is the curriculum components with a contribution ratio (0.592).

Table 12 The sequence of factors for the factor analysis of quality standards and labor market requirements.

\begin{tabular}{|r|r|r|}
\hline No. & Variables & Contribution ratio \\
\hline 1 & Training & 0.831 \\
\hline 2 & Relationship With The Labor Market & 0.758 \\
\hline 3 & Educational Activities & 0.725 \\
\hline 4 & Methods Of Teaching And Learning & 0.669 \\
\hline 5 & Evaluation Questions & 0.644 \\
\hline 6 & The Educational Objectives Of The Curriculum & 0.642 \\
\hline 7 & Curriculum Content & 0.592 \\
\hline
\end{tabular}

The outcomes of the factor analysis to determine the contribution rates of quality standards and labor market requirements in the curriculum of the College of Business Administration indicate a clear discrepancy in the contribution rates of the seven variables when implemented by the college administration. Thus, the answers of the study sample indicate the rejection of the hypothesis that there is no discrepancy in the quality standards and labor market requirements in the curriculum of the College of Business Administration at Prince Sattam bin Abdulaziz University. Accepting the alternative hypothesis, which states that there is a difference in the quality standards and requirements of the labor market in the curriculum of the College of Business Administration at Prince Sattam bin Abdulaziz University.

\section{Conclusion}

By analyzing the questions of the previous axes and testing the hypothesis of the study, we find that improving the quality of higher education is one of the strategic objectives of all higher education organizations looking to achieve leadership and excellence. Where the results showed that there is a clear discrepancy in the contribution rates for the seven variables when implemented by the college 
administration. Thus, the answers to the study sample indicate the existence of a discrepancy in the quality standards and labor market requirements in the college curriculum. Therefore, the college must link the curriculum with the learning objectives and define the components of the curriculum in a way that raises the various skills of the student and reconsider the current curriculum and take advantage of the curriculum quality standards related to society and the labor market, and linking the development process with society, and developing the relationship with private sector organizations for the purpose of supporting the specialized curriculum and coordinating with those organizations in order for training to take place in their organizations, as well as conducting accurate scientific studies of educational outcomes, and the specifications of the graduate student, and the suitability of the disciplines with the labor market and the needs of the community, for the purpose of making a change in some programs, and adding new academic programs, and it is also necessary to focus on the practical aspect of studying students and work on developing the study lecture to be electronically and to benefit from the technological development and reflect it on the teaching process.

\section{Acknowledgment}

The researcher extends his sincere thanks to the Deanship of Scientific Research at Prince Sattam bin Abdulaziz University for its continuous support and contributions in the field of scientific research.

\section{References}

Ahmed, A. (2019). The quality of university education and its impact on the values of sustainable development. Management Science Letters, 8(3), 231-245.

Al-Hazmi, N. (2020). Internal marketing policies and procedures at Prince Sattam Bin Abdulaziz University and the extent of workers' satisfaction. Management Science Letters, 10(7), 1427-1436.

Alheliwo, A. (2020). Measuring the quality of life of university students. Journal of Administration and Economics, University of Baghdad, 2(12), 428-439.

Hasen, H. (2019). Education Standard for the Staff or Art College-Basra University. Basra Literature Journal, 1(59), 125-142.

Kaiso, T. (2019). Requirements to meet the quality of accounting education on the application of the accounting department. Journal of Administrative and Financial Sciences, 1(7), 356-370.

Mahrri, S. (2017). Quality Assurance in Higher Education Standards. Arab Journal of Social Studies and Research, 1(24), 240-255.

Natheir, A. (2017). Measuring Quality and Requirements of the Labor Market in Private High Education Curriculum satisfaction. Altourath University Journal, 19(6), 425-436.

Sabri, H. (2019). The quality of higher education and academic accreditation standards. Arab Journal for Quality Assurance of Education, 4(9), 560-586. 